Research Article

\title{
Effect of Sodium Aluminate Dosage as a Solid Alkaline Activator on the Properties of Alkali-Activated Slag Paste
}

\author{
Bin Chen, Jun Wang ${ }^{D}$, and Jinyou Zhao $(\mathbb{D}$ \\ College of Civil Engineering, Northeast Forestry University, Harbin 150040, China \\ Correspondence should be addressed to Jun Wang; jun.w.619@nefu.edu.cn and Jinyou Zhao; jinyou2000@nefu.edu.cn
}

Received 13 October 2020; Accepted 21 December 2020; Published 6 January 2021

Academic Editor: Robert Černý

Copyright (C) 2021 Bin Chen et al. This is an open access article distributed under the Creative Commons Attribution License, which permits unrestricted use, distribution, and reproduction in any medium, provided the original work is properly cited.

\begin{abstract}
Extensive research into alkali-activated slag as a green gel material to substitute for cement has been done because of the advantages of low-carbon dioxide emissions and recycling of industrial solid waste. Alkali-activated slag usually has good mechanical properties, but the too fast setting time restricted its application and promotion. Changing the composition of alkaline activator could optimize setting time, usually making it by adding sodium carbonate or sodium sulfate but this would cause insufficient hydration reaction power and hinder compressive strength growth. In this paper, the effect of sodium aluminate dosage as an alkaline activator on the setting time, fluidity, compressive strength, hydration products, and microstructures was studied through experiments. It is fair to say that an appropriate amount of sodium aluminate could obtain a suitable setting time and better compressive strength. Sodium aluminate provided enough hydroxyl ions for the paste to promote the hydration reaction process that ensured obtaining high compressive strength and soluble aluminium formed precipitate wrapped on the surface of slag to inhibit the hydration reaction process in the early phase that prolonged setting time. The hydration mechanism research found that sodium aluminate played a key role in the formation of higher cross-linked gel hydration products in the late phase of the process. Preparing an alkali-activated slag with excellent mechanical properties and suitable setting time will significantly contribute to its application and promotion.
\end{abstract}

\section{Introduction}

Cement as one of the most common commodities has been widely used all over the world [1]. The production of cement consumed a large number of mineral resources and electricity, emitting big quantities of carbon dioxide that account for $5-8 \%$ of the total global carbon dioxide emissions, which caused serious damage to the ecological environment [2]. Therefore, it is urgent to find a low-carbon environmentfriendly gel material to substitute cement. Alkali-activated slag (AAS) used industrial solid waste slag as raw material, formed to gel material under strong alkali excitation; in this case, it was extreme to be the green ecofriendly substitution of cement $[3,4]$.

AAS had the characteristics of low-carbon dioxide emissions and recycling of industrial solid waste, and the advantages of its good early-phase mechanical properties, high-temperature resistance, and strong corrosion resistance had been proved by many studies [5]. However, the disadvantages of AAS were the too fast setting time, cumbersome preparation process, and alkali corrosive damage; these points restricted the AAS application and promotion. Scholars spent lots of effort in solving the AAS too fast setting time and reported that the composition and content of alkaline activator were the effect factors of AAS setting time. Jiao et al. [6] demonstrated that to add $\mathrm{Na}_{2} \mathrm{CO}_{3}$ to $\mathrm{NaOH}$ as an alkaline activator could extend the setting time obviously, but the compressive strength was seriously lost. Cengiz Duran Atişt et al. [7] found that to use $\mathrm{Na}_{2} \mathrm{CO}_{3}$ as an alkaline activator could obtain a longer setting time than $\mathrm{NaSiO}_{3}$ and $\mathrm{NaOH}$ by experiment. Longer setting time led to uncompleted hydration reaction which resulted in low compressive strength when $\mathrm{Na}_{2} \mathrm{CO}_{3}$ was used as an alkaline activator. Furthermore, the calcite was generated that $\mathrm{Na}_{2} \mathrm{CO}_{3}$ was used as an alkaline activator, which was harmful to compressive strength growth. Rashad et al. [8] 
believed that choosing $\mathrm{Na}_{2} \mathrm{SO}_{4}$ as an alkaline activator could earn long setting time and low compressive strength played out at a slow rate. Previous research found that changing the alkaline activator composition by adding $\mathrm{Na}_{2} \mathrm{CO}_{3}$ and $\mathrm{Na}_{2} \mathrm{SO}_{4}$ could delay setting time but result in low compressive strength which was a key property for AAS. On the other hand, as mentioned by Sakulich et al. [9] and Huang and Han [10], changing the $\mathrm{Si} / \mathrm{Al}$ ratio of the paste by adding $\mathrm{Al}_{2} \mathrm{O}_{3}$ could obtain a suitable setting time, and the problem of low compressive strength also existed. The addition of $\mathrm{Al}_{2} \mathrm{O}_{3}$ generated precipitates wrapped on the surface of slag in the early phase and the hydration reaction was inhibited that caused a long setting time [11]. The low concentration of $\mathrm{OH}^{-}$ions in the late phase of hydration reaction was because of the increased of $\mathrm{Al}^{3+}$ ions which consumed a large number of $\mathrm{OH}^{-}$ions in the paste and led to insufficient hydration reaction power and then hard to generate highly cross-linked gel which was the main reason of low growth ratio of AAS compressive strength.

Many experts already noted that $\mathrm{Na}_{2} \mathrm{SiO}_{3}$ provided more $\mathrm{Si}^{4+}$ and $\mathrm{OH}^{-}$ions for the paste which promoted the hydration reaction progress and obtained better mechanical properties, but the too fast setting time happened against the actual operation. Although adding $\mathrm{Na}_{2} \mathrm{CO}_{3}, \mathrm{Na}_{2} \mathrm{SO}_{4}$, and $\mathrm{Al}_{2} \mathrm{O}_{3}$ could avoid too fast setting time, the big consumption or lack of much $\mathrm{OH}^{-}$ions resulted in insufficient hydration power which led to the slow growth ratio of AAS compressive strength. As we all know, the hydration power of AAS mainly relied on the number of $\mathrm{OH}^{-}$ions carried by the alkaline activator. Therefore, we here proposed using $\mathrm{NaAlO}_{2}$ as an alkaline activator and studied the effects on the setting time, fluidity, and mechanical properties of AAS. A large number of $\mathrm{OH}^{-}$ions and more soluble $\mathrm{Al}^{3+}$ ions were provided by the addition of $\mathrm{NaAlO}_{2}$ which ensured better mechanical properties and delayed the hydration reaction rate, respectively. This paper studied the $\mathrm{NaAlO}_{2}$ dosage effects on properties of fresh and hardened $\mathrm{Na}_{2} \mathrm{SiO}_{3}$ based AAS paste. Considering the cumbersome preparation process of liquid alkaline activator and the alkali corrosion damage during the preparation and curing, this study proposed to used solid $\mathrm{NaAlO}_{2}$ and $\mathrm{Na}_{2} \mathrm{SiO}_{3}$ as a composite alkaline activator. The benefit was that the slag and the solid alkaline activator were dry mixture initially and stored. The way of using was the same as cement by adding water and mixing them directly, which improved the operation convenience and reduced alkali corrosion damage.

In this article, the effect of five different $\mathrm{NaAlO}_{2}$ dosages and five different $\mathrm{Na}_{2} \mathrm{O}$ contents on the setting time, fluidity, and compressive strength of AAS was studied. In addition, XRD, SEM-EDS, and FT-IR were used to analyze the hydration products, microstructures, and the vibration of chemical bonds in order to deeply explore the influence of $\mathrm{NaAlO}_{2}$ on the hydration mechanism.

\section{Materials and Test Methods}

2.1. Materials. The chemical components and the photograph of the slag are shown in Table 1 and Figure 1, respectively. Blast furnace slag was used with a specific gravity
TABLE 1: Chemical components of blast furnace slag (\%).

\begin{tabular}{ccccccccc}
\hline & $\mathrm{SiO}_{2}$ & $\mathrm{Al}_{2} \mathrm{O}_{3}$ & $\mathrm{CaO}$ & $\mathrm{MgO}$ & $\mathrm{MnO}$ & $\mathrm{TiO}_{2}$ & $\mathrm{~S}$ & $\mathrm{FeO}$ \\
\hline $\mathrm{S} 95$ & 32.93 & 14.98 & 40.92 & 8.01 & 0.55 & 0.93 & 0.89 & 0.79 \\
\hline
\end{tabular}

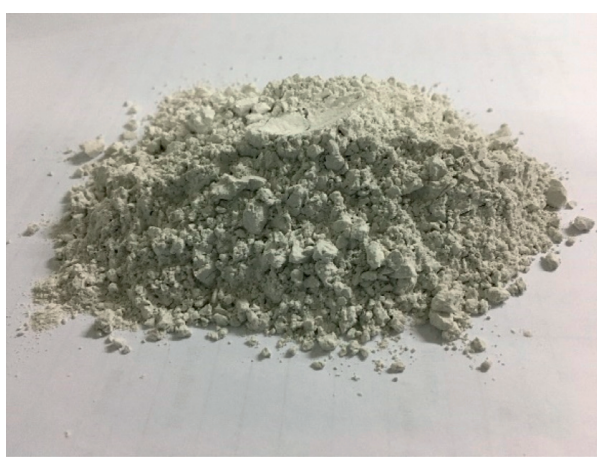

Figure 1: Photograph of blast furnace slag.

of $2.9 \mathrm{~g} / \mathrm{cm}^{3}$ and a specific surface of $435 \mathrm{~m}^{2} / \mathrm{kg}$ obtained from Minmetals Yingkou Medium Plate (Yingkou, China). According to the GB/T 18046-2017 [12], the slag was classified as S95. The composite solid alkaline activator was made by the mixture of solid $\mathrm{NaAlO}_{2}$ and solid $\mathrm{Na}_{2} \mathrm{SiO}_{3}$. $\mathrm{NaAlO}_{2}$ solid (analytical pure) was provided by Dalu Chemical Reagent Factory (Tianjin, China). $\mathrm{Na}_{2} \mathrm{SiO}_{3}$ solid $\left(\mathrm{Na}_{2} \mathrm{SiO}_{3} \cdot 9 \mathrm{H}_{2} \mathrm{O}\right.$; ratio of $\mathrm{Na}_{2} \mathrm{O}$ to $\mathrm{SiO}_{2}$ content was $1.03 \pm 0.03)$ was provided by Xilong Scientific Chemical Reagent Factory (Shantou, China). PO 42.5 cement (control group) was provided by Dalian Tianrui Cement Limited Company (Dalian, China).

2.2. Sample Preparation. Alkaline activators preparation, six different $\mathrm{NaAlO}_{2}$ dosages, and five different $\mathrm{Na}_{2} \mathrm{O}$ contents of $0 \%, 20 \%, 40 \%, 60 \%, 80 \%, 100 \%$ and $3 \%, 5 \%, 7 \%, 9 \%, 11 \%$, respectively, were used. The water-to-slag ratio was kept constant at 0.35 . The mixture proportions summary is shown in Table 2. For instance, the number "A8S2-5M" represented the alkaline activator with $80 \% \mathrm{NaAlO}_{2}$ dosage $\left(\mathrm{NaAlO}_{2}\right.$-to- $\mathrm{Na}_{2} \mathrm{SiO}_{3}$ ratio of $80 / 20$ ) and $5 \% \mathrm{Na}_{2} \mathrm{O}$ content. For AAS preparation, firstly premix the solid composite alkaline activator $\left(\mathrm{NaAlO}_{2}\right.$ and $\left.\mathrm{Na}_{2} \mathrm{SiO}_{3}\right)$, slag for $2 \mathrm{~min}$, and then add water. The whole mixture was agitated for $4 \mathrm{~min}$, the first $2 \mathrm{~min}$ at a slow rate of $200 \pm 5 \mathrm{rpm}$ and a fast rate of $400 \pm 10 \mathrm{rpm}$ for the other $2 \mathrm{~min}$. The AAS preparation process is shown in Figure 2. The cement test of the control group was used PO 42.5 cement (“C- 1 ”). The water-tocement ratio remained constant at 0.5 .

2.3. Test Methods. The setting time test was implemented by the Vicat equipment on the basis of GB/T 1346-2011 [13]. Measuring at room temperature, directly the fresh paste was poured into the truncated conical mold $(h=40 \mathrm{~mm}$, $d_{\text {top }}=65 \mathrm{~mm}, d_{\text {bottom }}=70 \mathrm{~mm}$ ). The amount of fixed slag for each group was $500 \mathrm{~g}$. The definition of initial setting time was from adding water into slag to the paste permeated $4 \pm 1 \mathrm{~mm}$ value. The final setting time was defined until the 
TABLE 2: Mixture proportions summary.

\begin{tabular}{|c|c|c|c|c|c|c|}
\hline Code & $\mathrm{NaAlO}_{2}$ dosage (\%) & $\mathrm{Na}_{2} \mathrm{O}$ content $(\%)$ & Slag (g) & $\mathrm{NaAlO}_{2}(\mathrm{~g})$ & $\mathrm{Na}_{2} \mathrm{SiO}_{3}(\mathrm{~g})$ & $\mathrm{H}_{2} \mathrm{O}(\mathrm{g})$ \\
\hline A0S10-5M & 0 & 5 & 1500 & 0 & 344 & 525 \\
\hline A2S8-5M & 20 & 5 & 1500 & 39.7 & 275.2 & 525 \\
\hline A4S6-5M & 40 & 5 & 1500 & 79.4 & 206.4 & 525 \\
\hline A6S4-5M & 60 & 5 & 1500 & 119 & 137.6 & 525 \\
\hline A8S2-5M & 80 & 5 & 1500 & 158.7 & 68.8 & 525 \\
\hline A10S0-5M & 100 & 5 & 1500 & 198.4 & 0 & 525 \\
\hline $\mathrm{A} 2 \mathrm{~S} 8-3 \mathrm{M}$ & 20 & 3 & 1500 & 23.8 & 165.1 & 525 \\
\hline A2S8-7M & 20 & 7 & 1500 & 55.6 & 385.3 & 525 \\
\hline A2S8-9M & 20 & 9 & 1500 & 71.4 & 495.4 & 525 \\
\hline A2S8-11M & 20 & 11 & 1500 & 87.3 & 605.5 & 525 \\
\hline
\end{tabular}

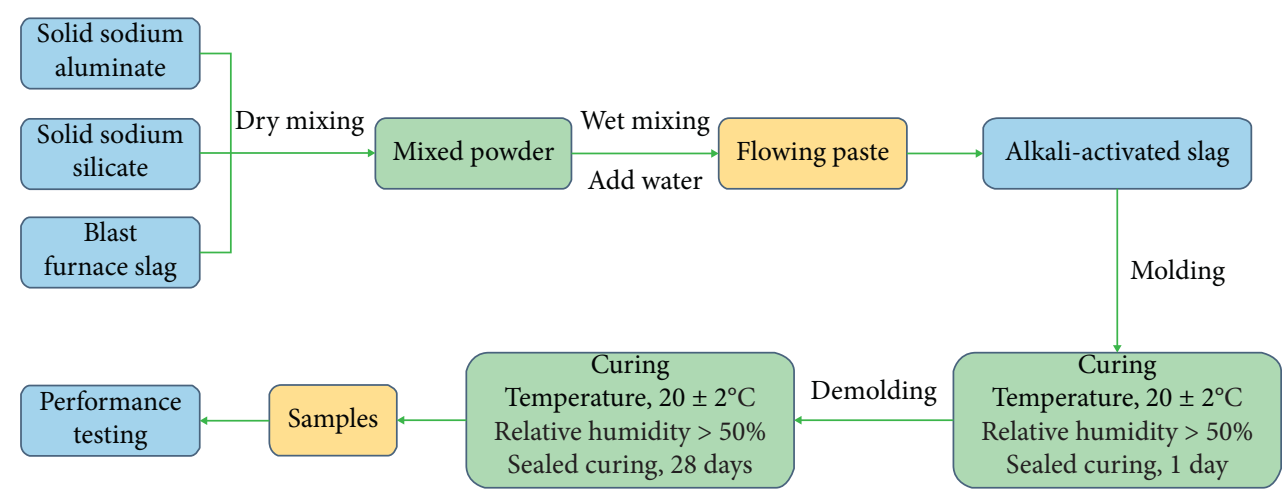

Figure 2: The AAS preparation process.

cyclic annular needle printed no mark twice in a row, on the surface of AAS paste.

The fluidity test used the truncated conical mold ( $\left.h=60 \mathrm{~mm}, d_{\text {top }}=36 \mathrm{~mm}, d_{\text {base }}=60 \mathrm{~mm}\right)$ under the standard GB/T 8077-2012 [14]. The amount of fixed slag for each group was $300 \mathrm{~g}$. Firstly pour the premixed paste into the mold, and then lift the mold after scraping the surface. The fluidity value was the average value of the two perpendicular directions measurements after $0.5 \mathrm{~min}$.

The pastes were poured into the cuboid mold ( $h=40 \mathrm{~mm}, w=40 \mathrm{~mm}, l=160 \mathrm{~mm}$ ) and then the paste was vibrated by machine for 2 min basing upon GB/T 176711999 [15]. After that, the paste was wrapped with plastic to avert evaporation and transferred into the curing room $\left(20 \pm 2^{\circ} \mathrm{C}\right.$ and $\left.\mathrm{RH}>50 \%\right)$ for $1 \mathrm{~d}$ curing time. After samples were demolded, they were kept in the curing room till the test schedule. Compressive strength was tested during 3, 7, and $28 \mathrm{~d}$ curing time and loaded at rate of $2.4 \mathrm{kN} / \mathrm{s}$ using the CL-automatic compressive strength appliance. The compressive strength value was defined by the mean value of three samples for each curing time.

After 3, 7, and 28 days of curing time compressive strength test, the specimens were obtained from the crushed samples and then poured into alcohol for 24 hours to discontinue hydration. Subsequently, the specimens were taken out from the alcohol and dried in a $60^{\circ} \mathrm{C}$ oven. For purpose of confirming the reaction mechanism and hydration products of AAS, the microtopography and elementary composition of hydration products were used by scanning electron microscopy with energy-dispersive spectrometry
(SEM/EDS) and X-ray diffraction (XRD), respectively (JEOL-6360LV, Japan and Empyrean-X, Netherlands). The properties of the bonds of slag and AAS products were surveyed by Fourier transform infrared spectroscopy (FTIR, PerkinElmer, America).

\section{Results and Discussion}

3.1. Setting Time. AAS setting time with different $\mathrm{NaAlO}_{2}$ dosages and $\mathrm{Na}_{2} \mathrm{O}$ contents is displayed in Figure 3. The AAS setting time was related to the $\mathrm{NaAlO}_{2}$ dosage and $\mathrm{Na}_{2} \mathrm{O}$ content, ranging from 80 to $840 \mathrm{~min}$. The initial and final setting times of $0 \% \mathrm{NaAlO}_{2}$ dosage were $80 \mathrm{~min}$ and $150 \mathrm{~min}$, respectively. The addition of $\mathrm{NaAlO}_{2}$ was able to prolong the setting time obviously, and the longest setting time was four times that of the shortest. The prolonged setting time was gradually shortened during the $\mathrm{NaAlO}_{2}$ dosage increasing from $20 \%$ to $60 \%$; the prolonged setting time was gradually extended when the $\mathrm{NaAlO}_{2}$ dosage increased between $60 \%$ and $100 \%$. It noted that the prolonged setting time does not become longer as the amount of $\mathrm{NaAlO}_{2}$ increased, meaning that the increased amount of $\mathrm{NaAlO}_{2}$ dosage does not have an absolutely positive correlation to the prolonged setting time. The different compositions and contents of the alkaline activator have an important influence on the hydration reaction rate. $\mathrm{NaAlO}_{2}$ prolonged setting time significantly, which could be explained by the active $\mathrm{Al}^{3+}$ ions from $\mathrm{NaAlO}_{2}, \mathrm{NaAlO}_{2}$ was hydrolyzed and then wrapped on the slag before part of slags dissolved, which caused slag dissolution suppressed. First, 


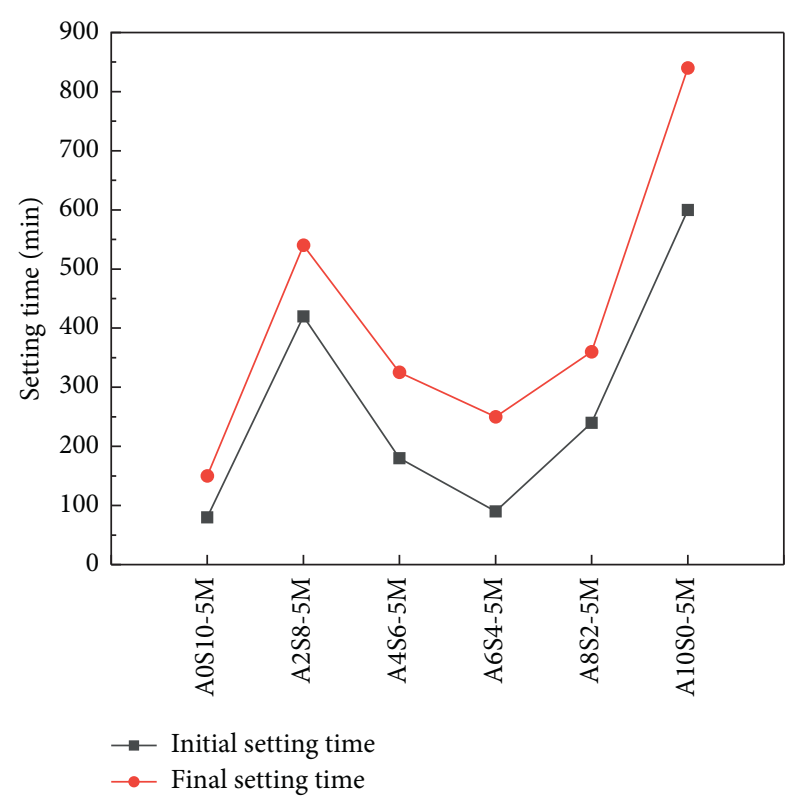

(a)

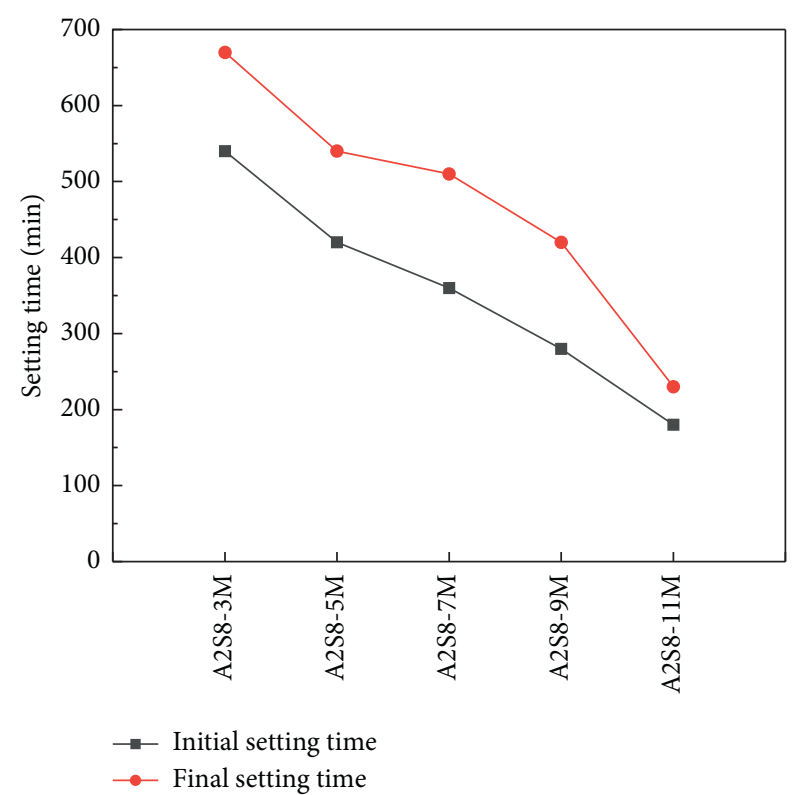

(b)

Figure 3: AAS setting time with different $\mathrm{NaAlO}_{2}$ dosages and $\mathrm{Na}_{2} \mathrm{O}$ contents. (a) Different $\mathrm{NaAlO}_{2}$ dosages and (b) different $\mathrm{Na}_{2} \mathrm{O}$ contents.

the free-stated $\mathrm{OH}^{-}$ions reacted with the active $\mathrm{Al}^{3+}$ wrapped on the surface of slag and the slag could only be further dissolved upon the first step is done, that is why the reaction was slow. Sakulich et al.'s [9] studies found that high concentrations of $\mathrm{Al}^{3+}$ would reduce the hydration reaction rate. However, Aydin and Baradan [16] believed that the prolonged setting time due to the active $\mathrm{Al}^{3+}$ could promote the hydration reaction in the early phase of reaction, but the resulting precipitates had no time to grow up and are hard to form a gel. Another possible reason was that the slag was fully dissolved due to high $\mathrm{OH}^{-}$ions concentration in the early phase of the hydration reaction sourced from the $\mathrm{NaAlO}_{2}$ hydrolysis. The gel generation occurred after the dissolution of slag in the hydration reaction, and most of the slag formed new gels after being dissolved, and it is fair to say that more complete dissolution could lead to longer hydration reaction time.

On the other hand, the AAS setting time was significantly getting shorter with the increase of $\mathrm{Na}_{2} \mathrm{O}$ content. The higher $\mathrm{Na}_{2} \mathrm{O}$ content in the alkaline activator meant more $\mathrm{OH}^{-}$ions in the slurry, which was the main factor that provided the hydration power to the paste. Therefore, even though the soluble $\mathrm{Al}^{3+}$ in $\mathrm{NaAlO}_{2}$ inhibited the hydration reaction, the higher $\mathrm{Na}_{2} \mathrm{O}$ content played an important role, which significantly accelerated the hydration reaction rate and shortened the setting time. Bakharev et al. [17] believed that high $\mathrm{Na}_{2} \mathrm{O}$ content meant higher $\mathrm{OH}^{-}$concentration in the slurry, which caused the decomposition of a large number of cations such as $\mathrm{Si}^{4+}, \mathrm{Al}^{3+}$, and $\mathrm{Ca}^{2+}$ in the slag, accelerated the process of depolymerization and polycondensation, and resulted in rapid gel formation, which shorten the setting time. Hence, adding $\mathrm{NaAlO}_{2}$ and reducing $\mathrm{Na}_{2} \mathrm{O}$ content would prolong the AAS setting time, and the appropriate setting time could be obtained by changing the $\mathrm{NaAlO}_{2}$ dosage and $\mathrm{Na}_{2} \mathrm{O}$ content.

3.2. Fluidity. Figure 4 shows AAS fluidity with different $\mathrm{NaAlO}_{2}$ dosages and $\mathrm{Na}_{2} \mathrm{O}$ contents of alkaline activators. All AAS fluidity was ranged from 60 to $203 \mathrm{~mm}$. The difference between the lowest (for A8S2-5M) and the highest (for A0S10-5M) fluidity was around three times. For all composite solid alkaline activators activated slag, the fluidity decreased by adding $\mathrm{NaAlO}_{2} \cdot \mathrm{NaAlO}_{2}$ hydrolyzed to $\mathrm{Al}^{3+}$ and $\mathrm{OH}$ - ions that would accelerate the process of hydration reaction [18], and Mehdizadeh and Najafi Kani [19] reported that the fluidity loss was due to the acceleration of slag decomposed and gel generated. Sasaki et al. [20] reported the slump flow values decreased with the $\mathrm{Al}^{3+}$ concentrations increasing. Another reason may be that the greater $\mathrm{NaAlO}_{2}$ dosage caused the weaker hydrolysis capacity of the paste resulting in a low rate of depolymerization of the slag, the final yield stress and apparent viscosity of the paste increased, and the fluidity gradually decreased. Xie et al. [21] believed that the decrease in yield stress would increase the fluidity of the paste. Besides, for all AAS samples, the fluidity declined with increasing $\mathrm{Na}_{2} \mathrm{O}$ content. High $\mathrm{Na}_{2} \mathrm{O}$ content resulted in high $\mathrm{Na}^{+}$and $\mathrm{OH}^{-}$ions concentration, which would generate more $\mathrm{Ca}^{2+}$ ions from the slag. Structural disintegration product numbers were continuously accumulated and the spatial liquid paste content between slag particles was constantly increased. It caused crowded of material particles and fluidity dropped. Puertas et al. [22] discovered that the fluidity decreased with increasing of $\mathrm{Na}_{2} \mathrm{O}$ content from $3 \%$ to $4 \%$ and indicated that the higher 


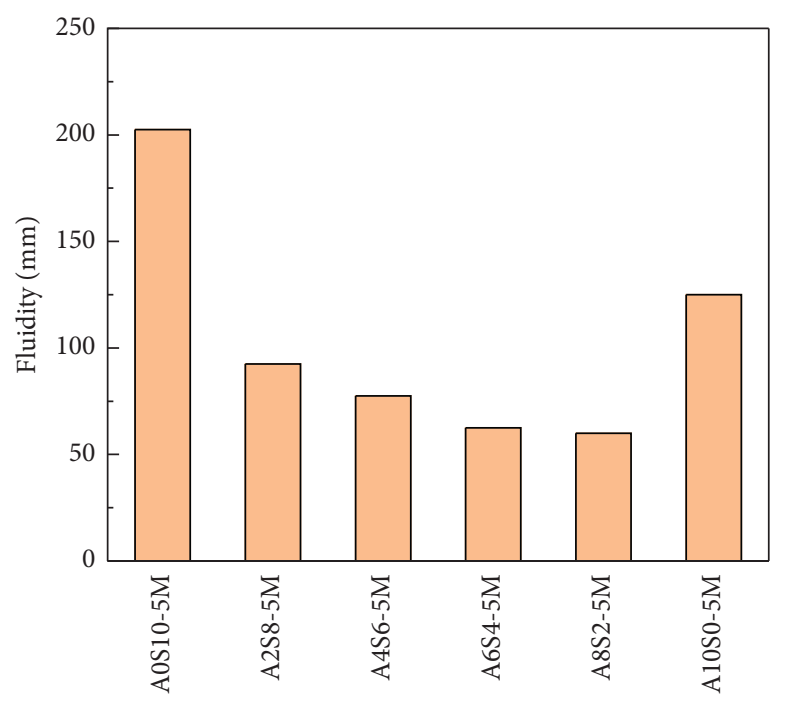

(a)

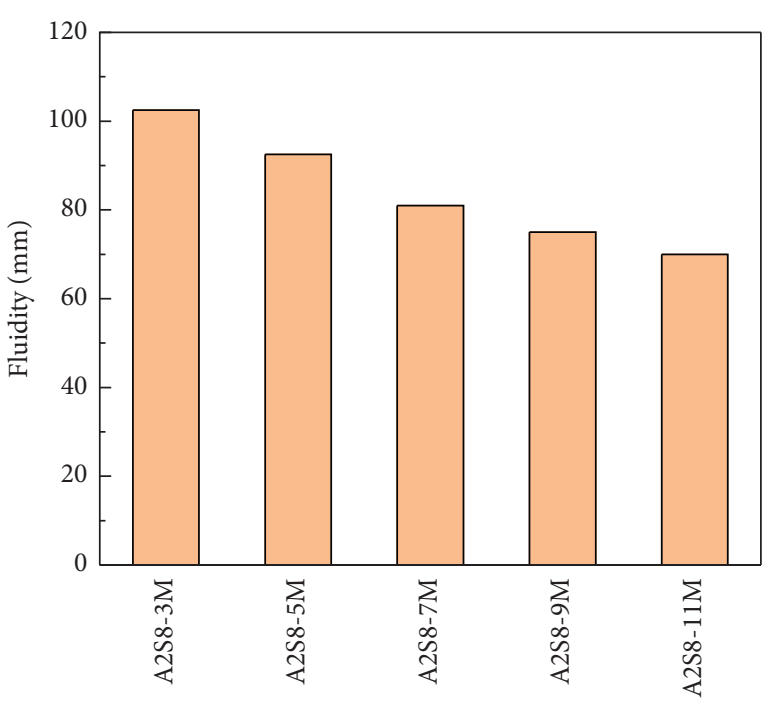

(b)

FIgure 4: AAS fluidity with different $\mathrm{NaAlO}_{2}$ dosages and $\mathrm{Na}_{2} \mathrm{O}$ contents. (a) Different $\mathrm{NaAlO}_{2}$ dosages and (b) different $\mathrm{Na}_{2} \mathrm{O}$ contents.

the yield stress, the lower the fluidity. Hence, the fluidity of AAS has found a strong connection to both $\mathrm{NaAlO}_{2}$ addition and $\mathrm{Na}_{2} \mathrm{O}$ content.

3.3. Compressive Strength. Figure 5 plots the AAS compressive strength with different $\mathrm{NaAlO}_{2}$ dosages and $\mathrm{Na}_{2} \mathrm{O}$ contents at 3,7 , and $28 \mathrm{~d}$ curing time. $20 \% \mathrm{NaAlO}_{2}$ dosage could significantly enhance the compressive strength of AAS at 3, 7, and $28 \mathrm{~d}$ compared with $0 \% \mathrm{NaAlO}_{2}$ dosage; it indicated that $\mathrm{NaAlO}_{2}$ could enhance the AAS compressive strength. The $28 \mathrm{~d}$ compressive strength of AAS had a positive correlation with $\mathrm{NaAlO}_{2}$ dosage when its amount increased from $40 \%$ to $100 \%$, but not perfect; the $3 \mathrm{~d}$ compressive strength of AAS was lower. The lower compressive strength was mainly due to the $\mathrm{Al}^{3+}$ ions from $\mathrm{NaAlO}_{2}$ initially wrapped on the surface of the slag particles in the early phase of hydration reaction, which inhibited the dissolution of the slag. With more $\mathrm{NaAlO}_{2}$ added, the said reaction frequency was more and led to low early compressive strength. The $3 \mathrm{~d}$ compressive strength of AAS with the $\mathrm{NaAlO}_{2}$ dosage of $40 \%, 60 \%$, and $80 \%$ was slightly lower than that dosage of $0 \%$. However, the rule was still followed which was the more $\mathrm{NaAlO}_{2}$ dosage caused the higher $3 \mathrm{~d}$ compressive strength. It could be indicated that although the cation in the $\mathrm{NaAlO}_{2}$ inhibited the hydration reaction, the higher $\mathrm{OH}^{-}$ions concentration by the addition of $\mathrm{NaAlO}_{2}$ promoted the hydration reaction more significantly. Abdalqader et al. [23] proved the $\mathrm{OH}^{-}$ions were significant to dissolve the slag glass structure and improve the process of hydration reaction.

It could be seen from the test results that the compressive strength of all AAS samples was constantly increased as the curing time increased, due to the highly gelled coagulation structure formed in the hydration product. FernandezJiménez et al. [24] noticed that it was a highly cross-linked condensed structure formed to enhance AAS compressive strength benefited from the curing time increasing. In addition, the $\mathrm{NaAlO}_{2}$ dosage had a significant impact on the $28 \mathrm{~d}$ compressive strength of AAS that higher $\mathrm{NaAlO}_{2}$ dosage led to higher compressive strength. It showed that $\mathrm{NaAlO}_{2}$ could promote the late phase of AAS hydration reaction, made for the formation of gel with higher compressive strength. On the one hand, $\mathrm{Al}^{3+}$ ions promoted the formation of higher cross-linked gel during the late-phase hydration reaction. On the other hand, the hydrolysis of $\mathrm{NaAlO}_{2}$ brought more $\mathrm{OH}^{-}$ions to the reaction solution and promoted the formation of more gels. Garcia et al. [18] found that $\mathrm{Al}^{3+}$ ions could promote the N-A-S-H gel to form $\mathrm{C}-\mathrm{A}-\mathrm{S}-\mathrm{H}$ gel in the late hydration reaction and enhanced the compressive strength. Kovtun et al. [25] reported the C-A$\mathrm{S}-\mathrm{H}$ gels in AAS products made higher compressive strength of AAS. It is undeniable that when $\mathrm{NaAlO}_{2}$ dosage was $100 \%$, the hydration reaction of the AAS was slow and compressive strength of 3 and $7 \mathrm{~d}$ was extremely low, which could also be confirmed by the setting time test results. Shi and Qian [26] believed the hydration reaction was too slow when aluminate was used as an alkaline activator. Too slow hydration reaction rate was not conducive to the application in engineering, which also fully showed that aluminate was not suitable to be used as an alkaline activator alone. Therefore, the $\mathrm{Al}^{3+}$ and $\mathrm{OH}^{-}$ions in $\mathrm{NaAlO}_{2}$ had an impact on certain stages of the AAS hydration reaction, delayed the setting time, and improved the compressive strength of AAS.

As shown in Figure 5(b), the compressive strength development rules of different $\mathrm{Na}_{2} \mathrm{O}$ contents at 3,7 , and $28 \mathrm{~d}$ curing time were similar. Compressive strength increased by the $\mathrm{Na}_{2} \mathrm{O}$ content raised from $3 \%$ to $5 \%$, but it declined by the $\mathrm{Na}_{2} \mathrm{O}$ content increased from $7 \%$ to $11 \%$. Therefore, the optimum $\mathrm{Na}_{2} \mathrm{O}$ content was $5 \%$, excessive $\mathrm{Na}_{2} \mathrm{O}$ content would reduce compressive strength. The $\mathrm{OH}^{-}$ions depolymerized $\mathrm{Al}^{3+}, \mathrm{Ca}^{2+}$, and other metal cations from the slag and formed new gels. However, the limited amount of slag led to an increase in the number of $\mathrm{OH}^{-}$ions, but there were 


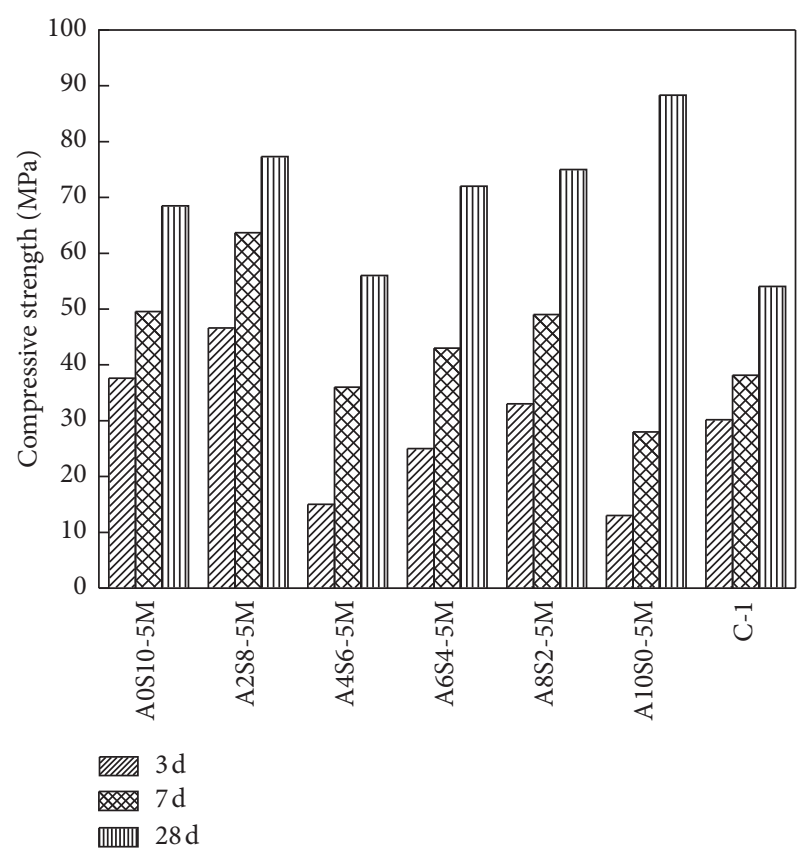

(a)

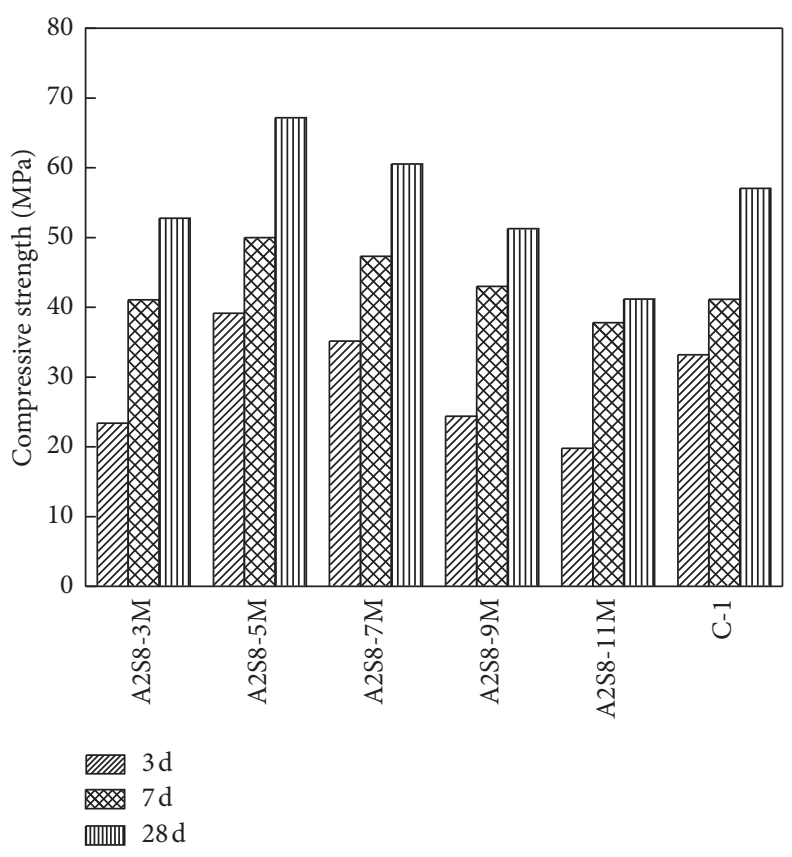

(b)

Figure 5: AAS compressive strength with different $\mathrm{NaAlO}_{2}$ dosages and $\mathrm{Na} 2 \mathrm{O}$ contents and cement. (a) Different $\mathrm{NaAlO}_{2}$ dosages and cement and (b) different $\mathrm{Na} 2 \mathrm{O}$ contents and cement.

not enough cations to combine with them to form a new gel, excessive $\mathrm{Na}_{2} \mathrm{O}$ content could not enhance the compressive strength of AAS continuously. On the contrary, more free state $\mathrm{OH}^{-}$ions would cause the compressive strength of AAS to weaken. Komnitsas et al. [27] reported that the alkaline activators of $8 \mathrm{M} \mathrm{KOH}$ and $8 \% \mathrm{Na}_{2} \mathrm{SiO}_{3}$ were most preferred by the compressive strength and indicated higher content would not be performed better. Jiao et al. [6] reported that among $4 \%, 6 \%$, and $8 \% \mathrm{Na}_{2} \mathrm{O}$ content of $\mathrm{Na}_{2} \mathrm{CO}_{3}$-to- $\mathrm{NaOH}$ as an alkaline activator, $6 \%$ obtained the best properties of the AAS paste. The compressive strength was obviously affected by the change of $\mathrm{Na}_{2} \mathrm{O}$ content and there was an optimum content. Hence, the AAS compressive strength was significantly affected by $\mathrm{NaAlO}_{2}$ dosage and $\mathrm{Na}_{2} \mathrm{O}$ content.

For the application of AAS, the comparison with the compressive strength of cement samples was extremely important. The $28 \mathrm{~d}$ compressive strength of all AAS samples and the 3 and $7 \mathrm{~d}$ compressive strength of most AAS samples were greater than the cement control group, respectively, according to the standard requirements of JGJ/T 439-2018 reaching the 62.5 level standard. Considering the setting time, fluidity and compressive strength, and outstanding advantages of AAS in protecting the environment, AAS could reach the performance requirements of cement and it is important to say AAS performed better in some aspects.

3.4. XRD. Figure 6(a) plots the XRD results of different $\mathrm{NaAlO}_{2}$ dosages. The reflected phenomenon at approximately $20-40^{\circ}$ of all AAS was the AAS characteristic reflected corresponding to the big quantity of amorphous products. Obviously, AAS main reaction products were $\mathrm{C}-\mathrm{S}-\mathrm{H}$ (I), gismondine and calcite, and little glaucophane. C-S-H (I) was the main paste of all AAS and was reflected phenomenon at around $30^{\circ}$ which existed in all specimens. Calcite was found in all paste and the reflected phenomenon of calcite and C-S-H (I) were overlapped; it caused C-S-H (I) to identify difficultly. The formation of calcite may be caused by sample carbonization during preparation and curing time. However, tetranatrolite was also a major product which was found in this research, and the tetranatrolite products amount increased by $\mathrm{NaAlO}_{2}$ dosage elevating. The generated tetranatrolite would cause more C-A-S-H to be generated, which had higher compressive strength. Bae et al. [28] indicated that single or multiple zeolites formation had a strong correlation with the dosage of $\mathrm{NaAlO}_{2}$. Zeolite paste was formed by C-A-S-H gel and indicated that more C-A-S$\mathrm{H}$ structures are generated by elevating $\mathrm{NaAlO}_{2}$ contents, thereby improving the AAS compressive strength. Khalid et al. [29] reported that zeolites ease formed the amorphous aluminosilicate gel. Therefore, an increase in the amount of $\mathrm{NaAlO}_{2}$ would increase the compressive strength of the material. In addition, Bernal et al. [30] suggested that the amount of zeolite $\mathrm{Na}-\mathrm{P} 1$ formed was obviously dependent on the addition of $\mathrm{NaAlO}_{2}$.

Figures 6(b) and 6(c) show XRD images of different curing times of AAS. The increase in peak intensity could reflect the increased amount of hydration products. A0S10$5 \mathrm{M}$ had already produced a large amount of $\mathrm{C}-\mathrm{S}-\mathrm{H}$ gel at $3 \mathrm{~d}$ curing time; however, A10S0-5M had no obvious results at 3 and $7 \mathrm{~d}$ curing time. The peak intensity by the curing time increased and more products generated by the reactive process continued. Cao et al. [31] declared that the hydration products did not form large numbers of C-S-H (I) gel until 


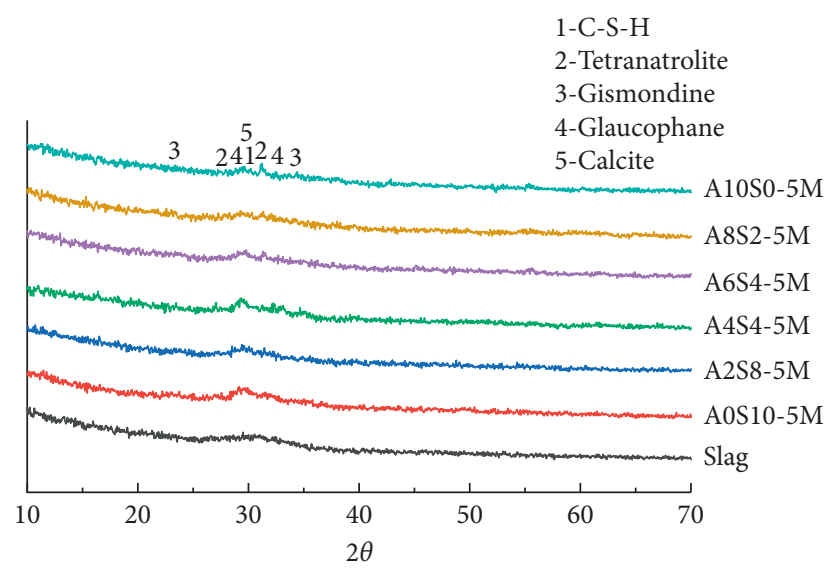

(a)

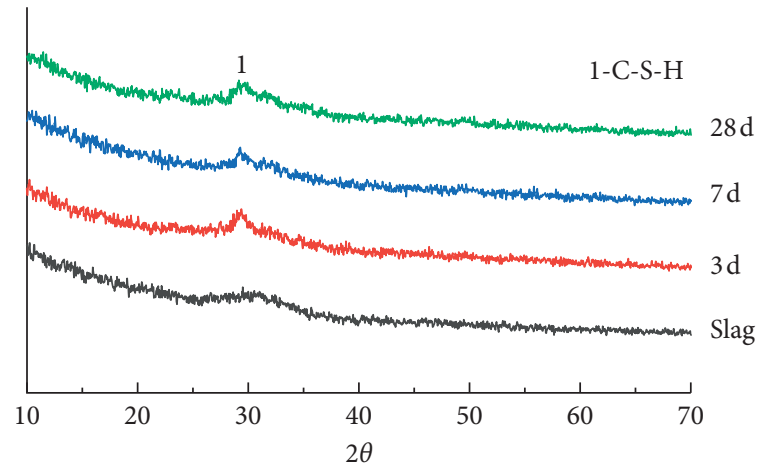

(b)

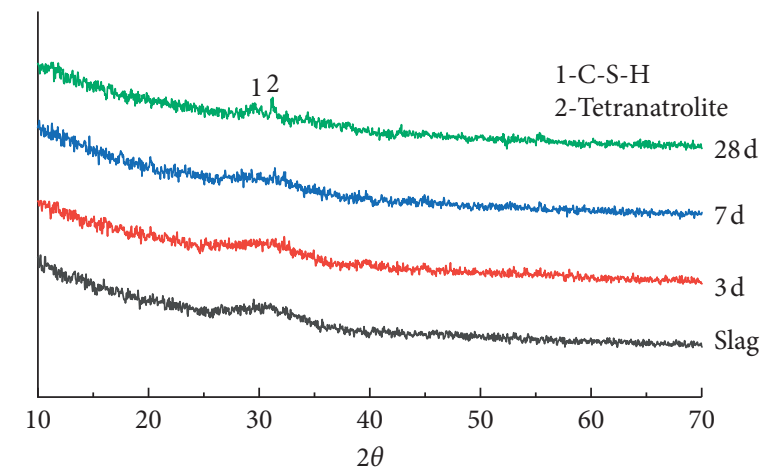

(c)

Figure 6: XRD images of AAS and raw slag. (a) Different $\mathrm{NaAlO}_{2}$ dosages at $28 \mathrm{~d}$ curing time and raw slag; (b) A0S10-5M at 3, 7, and 28 d curing time and raw slag; and (c) A10S0-5M at 3, 7, and $28 \mathrm{~d}$ curing time and raw slag.

$28 \mathrm{~d}$ curing time; much tetranatrolite was generated due to the addition of $\mathrm{NaAlO}_{2}$ and the maximum amount were formed at $28 \mathrm{~d}$, which correspond to the higher $28 \mathrm{~d}$ compressive strength and the SEM analysis.

3.5. SEM/EDS. Figure 7 demonstrates SEM micrographs of AAS at $3 \mathrm{~d}$ curing time. A0S10-5M and A2S8-5M slags had undergone dissolution and polycondensation reactions, resulting in a certain amount of amorphous gel structure and being bonded to the matrix on the outer surface of slags. Most of A6S4-5M and A8S2-5M slags had begun to dissolve and some amorphous gel structures had been produced. Most of A4S6-5M and A10S0-5M slags had not been dissolved, and only a small amount of amorphous gel structure had been generated. High $\mathrm{NaAlO}_{2}$ content had a certain inhibitory effect on early gel formation. Fernández-Jiménez et al. [32] demonstrated that particles coverage with formed aluminosilicates producing also a substantial slowdown of the reaction, retarding the dissolution of $\mathrm{Si}^{4+}$ and $\mathrm{Al}^{3+}$ required by the formation of gel. Gharzounia et al. [33] suggested that the $\mathrm{Al}^{3+}$ favored the precipitation of secondary reaction products and was negatived to geopolymer network. The microstructure characteristics interpreted compressive strength phenomenon of different $\mathrm{NaAlO}_{2}$ dosages at $3 \mathrm{~d}$ curing time, which corresponded to compressive strength analysis.

Figure 8 shows a SEM micrograph of A8S2-5M at $7 \mathrm{~d}$ curing time. Plenty of amorphous $\mathrm{C}-\mathrm{S}-\mathrm{H}$ gel structures were produced gradually, whose shape was mainly flaky and rarely fibrous. It shows that the degree of crystallization had increased at this time, but there were still a large number of voids, and the reactants had not been wrapped tightly to form a dense whole. The paste compressive strength was lower at the moment, which was corresponding to the compressive strength test results. Wang et al. [34] found some discontinuous pastes and voids were resulting from a less compact matrix and reduced performance of materials.

Figure 9 exhibits SEM micrographs of AAS at $28 \mathrm{~d}$ curing time. Still, unreacted slags in the specimen can be seen, but they were embedded in the gel to form a more homogeneous whole. A0S10-5M and A4S6-5M were not as enough dense as A8S2-5M, meaning their reaction was incomplete. On the other hand, A8S2-5M had a completed degree of reaction, it formed more homogeneous and smooth gels and enclosed unreactive materials, which was one of the main reasons for the dense structure and improved compressive strength. Composite solid alkaline activator activated slag materials that had better performance in $28 \mathrm{~d}$ curing time, and $\mathrm{NaAlO}_{2}$ was the crucial part in improving compressive strength in the reaction late phase. Huang et al. [35] reported that, at the 

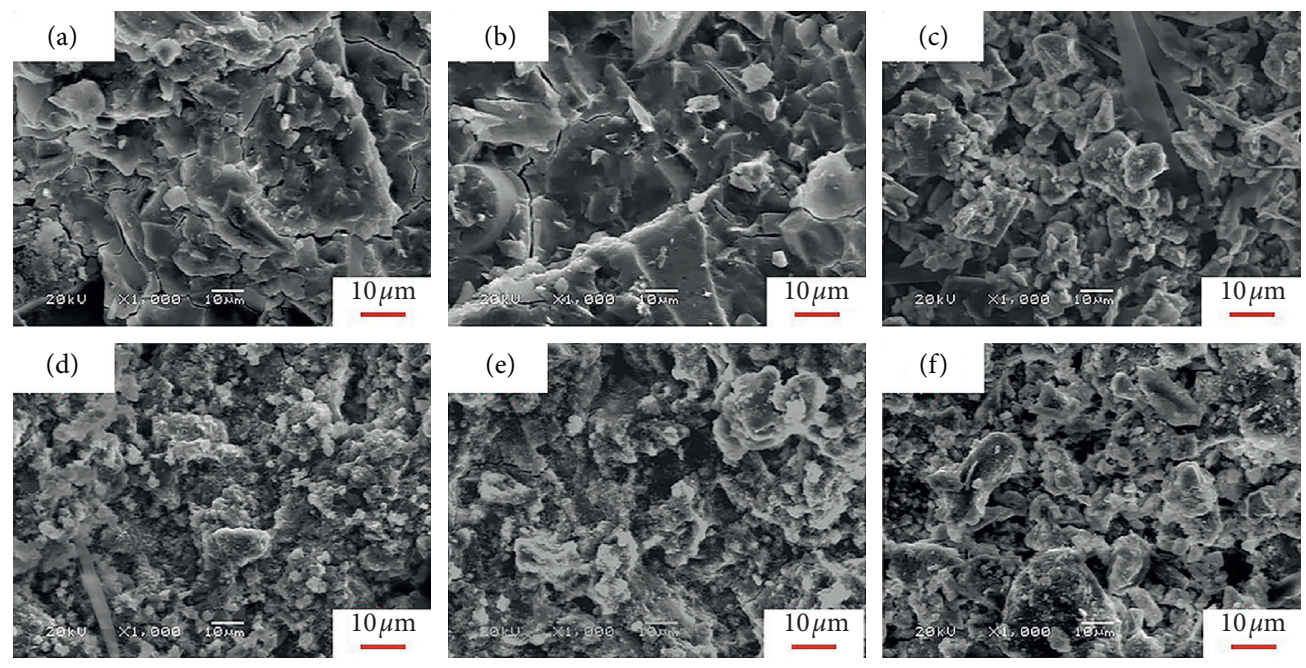

FIGURE 7: SEM micrographs of AAS at 3 d curing time. (a) A0S10-5M; (b) A2S8-5M; (c) A4S6-5M; (d) A6S4-5M; (e) A8S2-5M; (f) A10S0$5 \mathrm{M}$.

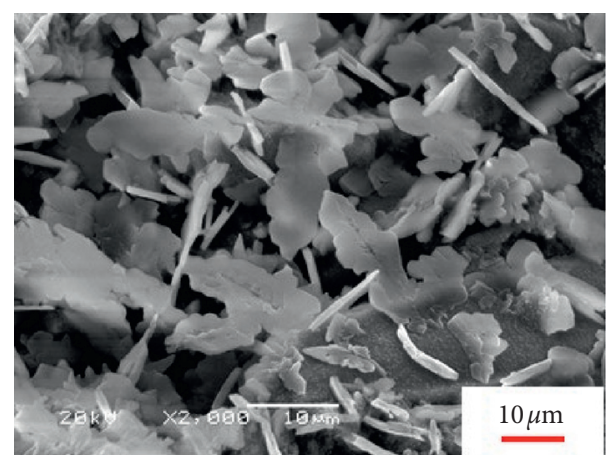

Figure 8: SEM micrograph of A8S2-5M at $7 \mathrm{~d}$ curing time.

late phase, the formation of larger secondary crystallization and a number of amorphous aluminosilicate minerals was filled in the voids, accelerating product generation. The AAS compressive strength development could be interpreted by the composition and morphology of paste.

Figures 10 and 11 are SEM/EDS images of A4S6-5M and A2S8-5M at $28 \mathrm{~d}$ curing time, respectively. Table 3 shows the EDS conclusions of the atomic ratios. The EDS analysis outcomes proved that the large share was $\mathrm{Ca}, \mathrm{Si}$, and $\mathrm{Al}$, and a relatively small share were held by $\mathrm{Na}$ and $\mathrm{Mg}$, which mostly contributed to the formation of C-A$\mathrm{S}-\mathrm{H}$ and C-S-H. The properties of C-S-H greatly depended on adjusting $\mathrm{Ca} / \mathrm{Si}$ ratios. Figures 9 and 10 show the $\mathrm{Ca} / \mathrm{Si}$ ratios of the measuring points were 0.99 and 1.05 which were defined as C-S-H (I), respectively, while the $\mathrm{Ca} / \mathrm{Si}$ ratios of ordinary Portland cement hydration products were greater than 1.5. Zhang et al. discovered the AAS $\mathrm{Ca} / \mathrm{Si}$ ratio was about 1.1. The molecular chain $\mathrm{Si}^{4+}$ of $\mathrm{C}-\mathrm{S}-\mathrm{H}$ (I) was easily replaced by part of $\mathrm{Al}^{3+}$ ions in the system, thereby generating C-A-S-H gel. Furthermore, the $\mathrm{Ca} / \mathrm{Si}$ ratios of $\mathrm{A} 2 \mathrm{~S} 8-5 \mathrm{M}$ were higher than A4S6-5M, which were 1.05 and 0.99 , respectively; thus, the number of $\mathrm{Si}-\mathrm{O}$ bonds produced by
A2S8-5M was higher than A4S6-5M and corresponded to the resulting compressive strength and FT-IR.

3.6. FT-IR. Figure 12 shows determinations of FT-IR for raw slag and AAS at $28 \mathrm{~d}$ curing time. The wavenumber of raw slag and AAS at $2000 \mathrm{~cm}^{-1}$ had no virtual diversity, as studies before approved. Raw slag FT-IR showed the wavenumber of $947 \mathrm{~cm}^{-1}$ certified the asymmetric stretching vibration existed which was $\mathrm{Si}-\mathrm{O}-\mathrm{Si}$ bonds or $\mathrm{Si}-\mathrm{O}-\mathrm{Al}$ bonds; those were relying on glass structures of raw slag. Besides, the $\mathrm{O}-\mathrm{C}-\mathrm{O}$ bonds were represented by the wavenumber of $1429 \mathrm{~cm}^{-1}$, indicating that the surface was carbonized.

AAS FT-IR indicated all AAS established similar bands, so similar products were proved. The same major wavenumbers of $3448,1629,1479,961,894$, and $439 \mathrm{~cm}^{-1}$ were found in all AAS at $28 \mathrm{~d}$ curing time. The wavenumber of $3348 \mathrm{~cm}^{-1}$ corresponded to the $\mathrm{O}-\mathrm{H}$ stretching bands, and $1629 \mathrm{~cm}^{-1}$ related to the $\mathrm{H}-\mathrm{O}-\mathrm{H}$ bending bands. Both of them stood as proof of C-(A)-S-H gel was produced and the hydration process. The wavenumber of $1479 \mathrm{~cm}^{-1}$ was related to the $\mathrm{C}=\mathrm{O}$ asymmetric bands, which was derived from $\mathrm{CO}_{2}$ in the atmosphere and $\mathrm{CO}_{3}{ }^{2-}$ generated by carbonization. The results 

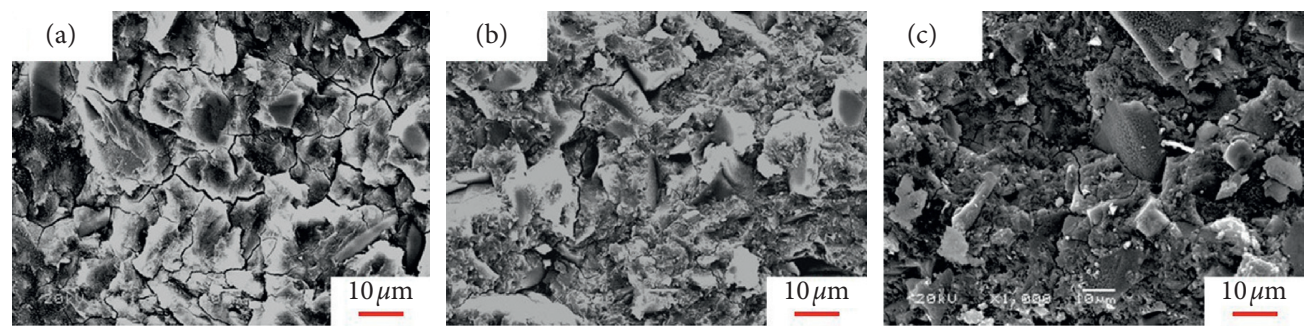

Figure 9: SEM micrographs of AAS at $28 \mathrm{~d}$ curing time. (a) A0S10-5M; (b) A4S6-5M; and (c) A8S2-5M.

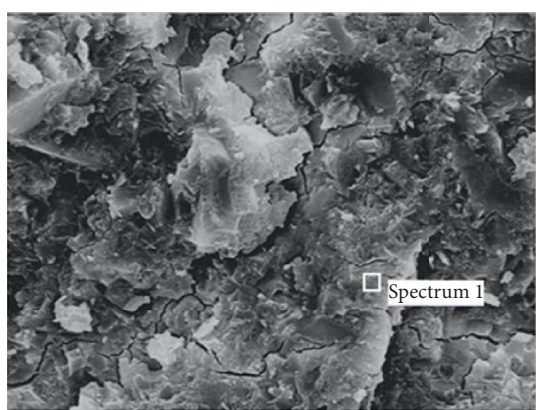

(a)

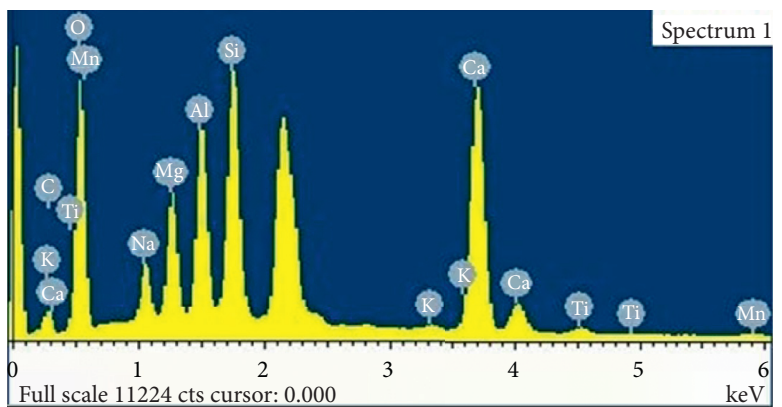

(b)

FIGURE 10: SEM/EDS photograph of A4S6-5M at $28 \mathrm{~d}$ curing time.

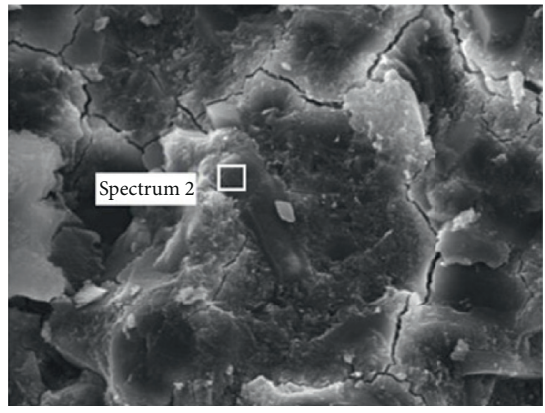

(a)

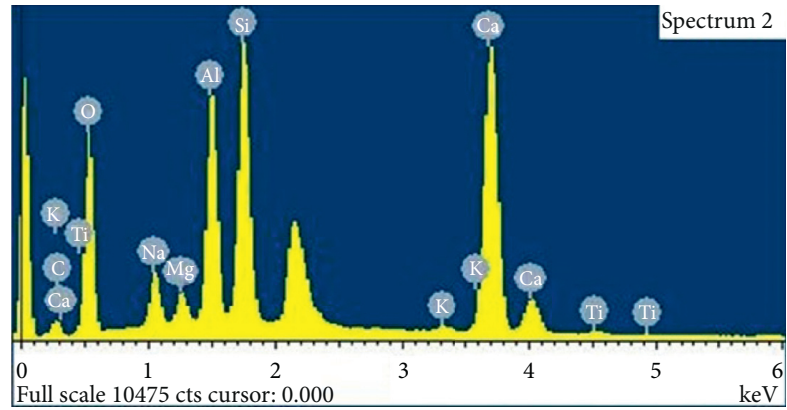

(b)

Figure 11: SEM/EDS photograph of A2S8-5M at $28 \mathrm{~d}$ curing time.

TABLE 3: A4S6-5M and A2S8-5M conclusions of atomic ratio at $28 \mathrm{~d}$ curing time (\%).

\begin{tabular}{lccccccc}
\hline Code & $\mathrm{O}$ & $\mathrm{Ca}$ & $\mathrm{Si}$ & $\mathrm{Al}$ & $\mathrm{Mg}$ & $\mathrm{Na}$ & $\mathrm{Ca} / \mathrm{Si}$ \\
\hline A4S6-5M & 61.08 & 7.22 & 7.26 & 5.71 & 4.69 & 3.09 & 0.99 \\
$\mathrm{~A} 2 \mathrm{~S} 8-5 \mathrm{M}$ & 62.35 & 9.6 & 9.17 & 7.30 & 1.36 & 3.35 & 1.05 \\
\hline
\end{tabular}

were related to the results of calcite generated by XRD analysis. The wavenumber of $961 \mathrm{~cm}^{-1}$ was the most typical characteristic bands of AAS, which represented the $\mathrm{Si}-\mathrm{O}-\mathrm{Si}(\mathrm{Al})$ asymmetric stretching bands. $\left[\mathrm{AlO}_{4}\right]^{5-}$ tetrahedron could replace $\left[\mathrm{SiO}_{4}\right]^{4-}$ tetrahedron on $\mathrm{Si}-\mathrm{O}-\mathrm{Si}$ chain during the reaction. Meanwhile, the alternating polycondensation of $\mathrm{Si}-\mathrm{O}$ bonds and $\mathrm{Al}-\mathrm{O}$ bonds occurred and caused microscopic changes in the internal structure. The $\mathrm{Si}-\mathrm{O}-\mathrm{Si}(\mathrm{Al})$ asymmetric stretching bands shifted obviously compared to slag. The wavenumber of $894 \mathrm{~cm}^{-1}$ was related to $-\mathrm{OH}$ bending bands, which together with the $\mathrm{Si}-\mathrm{O}-\mathrm{Si}(\mathrm{Al})$ asymmetric stretching bands proved that the alkali-activated reaction occurred. The wavenumber of $439 \mathrm{~cm}^{-1}$ was the bending vibration of the tetrahedron silicate corresponding to the $\left[\mathrm{SiO}_{4}\right]^{4-}$ tetrahedron bands of $\mathrm{O}-\mathrm{Si}-\mathrm{O}$ and $\mathrm{Si}-\mathrm{O}-\mathrm{Si}$. The bands were presented in AAS, and its intensity generally changed little, which was correlating to the $\mathrm{C}-\mathrm{S}-\mathrm{H}$ results of XRD.

Figure 12(b) plots the wavenumber of $610 \mathrm{~cm}^{-1}$ of A0S10-5M was Al-O-Si symmetrical stretching bands, which indicated the part of the $\left[\mathrm{AlO}_{6}\right]^{9-}$ octahedral structure in the slag was destroyed and transformed into $\left[\mathrm{AlO}_{4}\right]^{5-}$ tetrahedron. It illustrated that the 


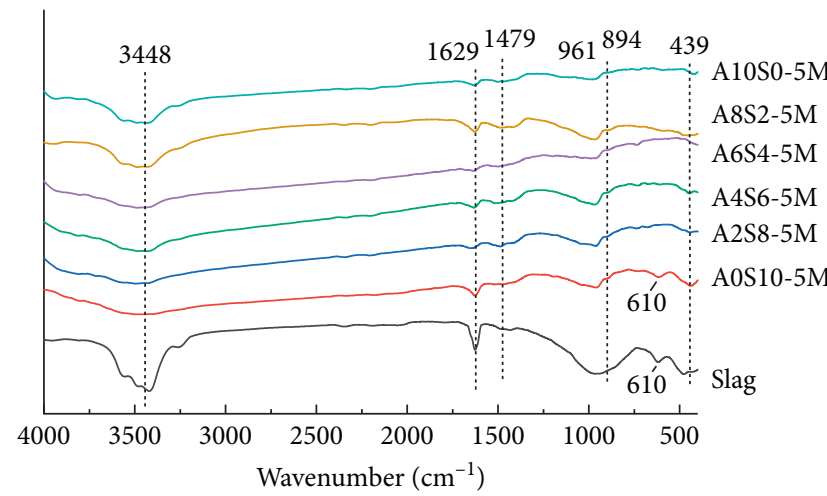

(a)

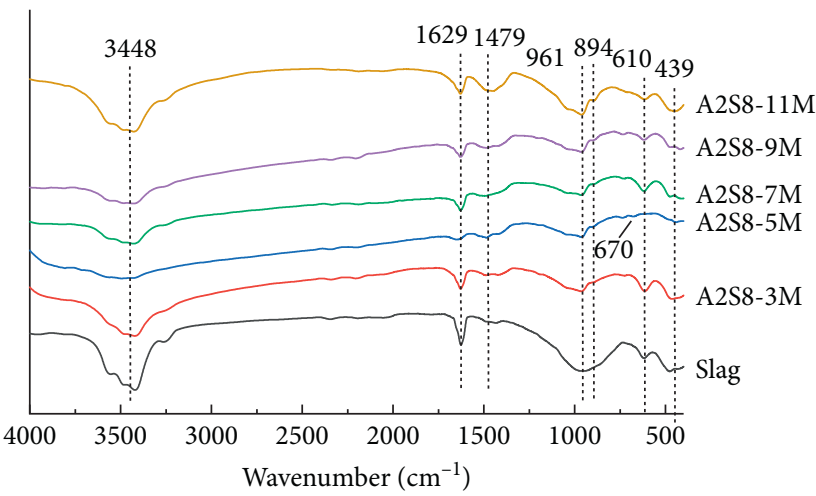

(b)

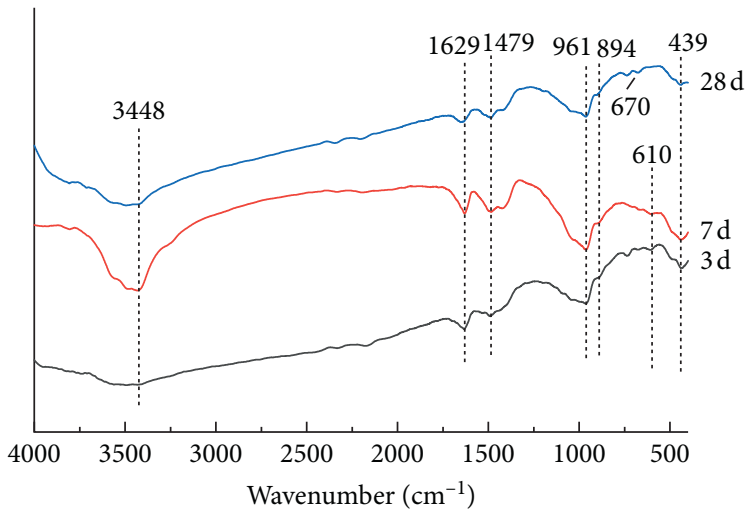

(c)

Figure 12: FT-IR spectra of AAS and raw slag. (a) Different $\mathrm{NaAlO}_{2}$ dosages at $28 \mathrm{~d}$ curing time; (b) different $\mathrm{Na}_{2} \mathrm{O}$ contents at $28 \mathrm{~d}$ curing time; and (c) A2S8-5M at 3, 7, and $28 \mathrm{~d}$ curing time.

depolymerization and repolymerization of the aluminosilicate glass body structure occurred. In addition, Figure 12(b) shows the A2S8-5M wave number of $670 \mathrm{~cm}^{-1}$ implying that the wavenumbers of $\mathrm{Si}-\mathrm{O}-\mathrm{T}$ stretching bands were higher than other samples with the same bands. The higher wavenumber of $\mathrm{Si}-\mathrm{O}-\mathrm{T}$ explained that the proportion of $\mathrm{Si}-\mathrm{O}-\mathrm{Si}$ bonds was more than $\mathrm{Si}-\mathrm{O}-\mathrm{Al}$ bonds. And the energy strength of $\mathrm{Si}-\mathrm{O}-\mathrm{Si}$ bonds was stronger than $\mathrm{Si}-\mathrm{O}-\mathrm{Al}$ bonds. Hence, A2S8$5 \mathrm{M}$ carried the best compressive strength among all samples, which corresponded to the compressive strength results.

Figure 12(c) shows that the wavenumbers of $\mathrm{Si}-\mathrm{O}-\mathrm{T}$ stretching bands at $28 \mathrm{~d}$ curing time (at $670 \mathrm{~cm}^{-1}$ ) were higher than the $\mathrm{Si}-\mathrm{O}-\mathrm{T}$ stretching bands at 3 and $7 \mathrm{~d}$ curing time (at $610 \mathrm{~cm}^{-1}$ ). As said above, the proportion of $\mathrm{Si}-\mathrm{O}-\mathrm{Si}$ bonds was more than $\mathrm{Si}-\mathrm{O}-\mathrm{Al}$ bonds as the hydration reaction continued, which was corresponding to the high $28 \mathrm{~d}$ compressive strength results.

3.7. Analysis of Hydration Mechanism. Based on the macroand microtest results and analyses, the hydration mechanism of $\mathrm{NaAlO}_{2}$ as a solid alkaline activator was as follows: the raw slag gradually reacted and dissolved under the action of composite solid alkaline activators, and the concentrations of soluble $\mathrm{Si}^{4+}$ and $\mathrm{Al}^{3+}$ ions in slag determined the chemical activity. In the reaction, the $\mathrm{Si}-\mathrm{O}-\mathrm{Si}$ and $\mathrm{Si}-\mathrm{O}-\mathrm{Al}$ bonds were broken and recombined with hydroxyl groups to form the $\mathrm{Si}(\mathrm{OH})_{4}$ and $\left[\mathrm{Al}(\mathrm{OH})_{4}\right]^{-}$. The $\mathrm{OH}^{-}$ions as the activator of the reaction provided the environment. Subsequently, $\mathrm{Si}(\mathrm{OH})_{4}$ and $\left[\mathrm{Al}(\mathrm{OH})_{4}\right]^{-}$underwent polycondensation and formed a multimer sol. At this time, the monovalent cations may be filled in the ring structure to balance the charge. With concentrations of ions increased, polycondensation reaction occurred between them, reformed the $\mathrm{Si}-\mathrm{O}-\mathrm{Al}$ and $\mathrm{Si}-\mathrm{O}-\mathrm{Si}$ dimer structures, and thereby formed a cyclic polymer with a longer $\mathrm{Si}-\mathrm{O}$ chain hydrated sodium aluminosilicate gel by polycondensation reaction continuing. The addition of $\mathrm{NaAlO}_{2}$ provided more charged particles and hydrated hydroxyl groups on the surface, which may generate soluble $\mathrm{Al}^{3+}$ and $\left[\mathrm{Al}(\mathrm{OH})_{4}\right]^{-}$. In the early phase, active soluble $\mathrm{Al}^{3+}$ wrapped the $[\mathrm{SiO} 4]_{4}^{-}$tetrahedron, which stopped the $\mathrm{Si}^{4+}$ reaction. However, in the late phase, active soluble $\mathrm{Al}^{3+}$ easily replaced the bridge $\left[\mathrm{SiO}_{4}\right]^{4-}$ tetrahedron to play the role of "bridge" and promoted the polycondensation reaction between $\mathrm{Si}(\mathrm{OH})_{4}$ and $\left[\mathrm{Al}(\mathrm{OH})_{4}\right]^{-}$. It was noticed from the test results that $\mathrm{Al}^{3+}$ in the $\mathrm{NaAlO}_{2}$ inhibited the hydration reaction progress in the early-phase hydration reaction, but the $\mathrm{OH}^{-}$ions in the $\mathrm{NaAlO}_{2}$ promoted the hydration reaction progress more obviously. In the late hydration reaction, the $\mathrm{Al}^{3+}$ ions and $\mathrm{OH}$ - had a dual role which promoted the formation of the highly cross-linked gel. Hence, the bridging oxygen structure in the polymer may be stabilized, formed a higher polymer, and caused the mechanical properties of the materials improved. Figure 13 shows schematic diagram of the 

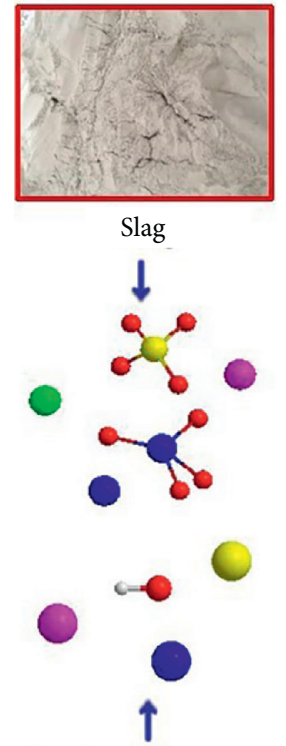

Alkaline activator

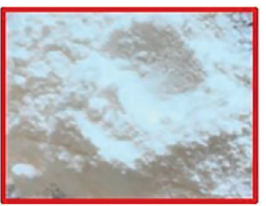

(a)
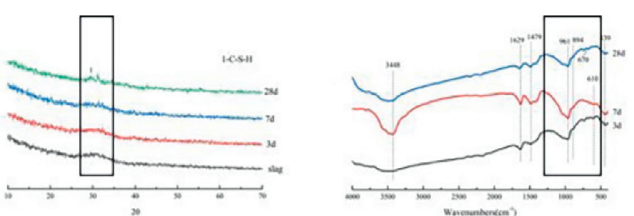

Generate gel $\uparrow$

† Generate multimer sol

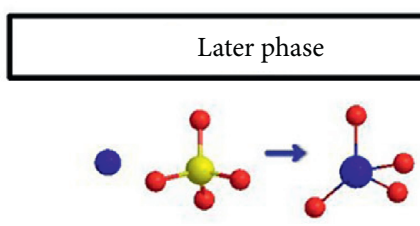

Substitution of Si with $\mathrm{Al}$
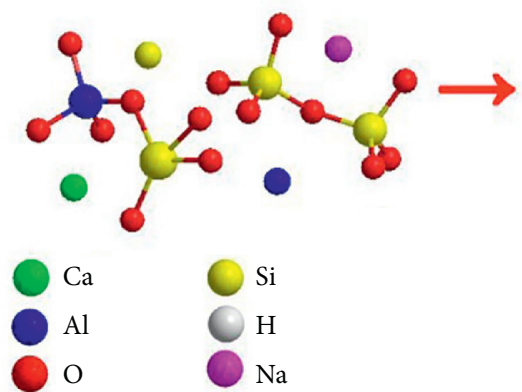

(b)
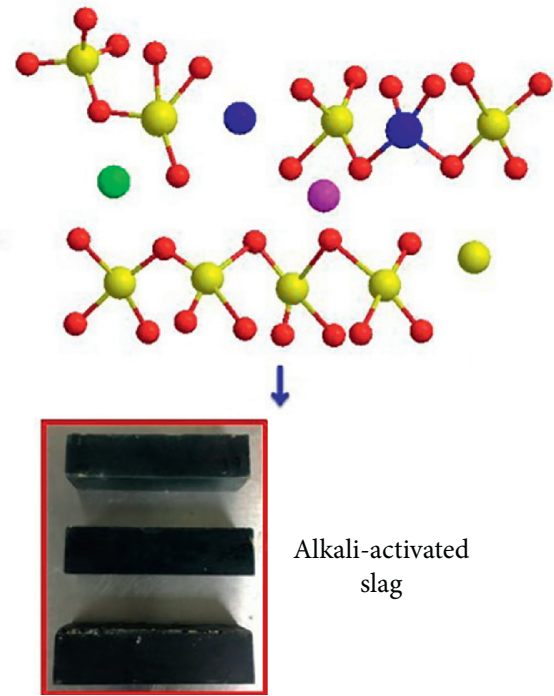

(c)

Figure 13: Schematic diagram of the main hydration process of fresh and hardened slag based $\mathrm{NaAlO}_{2}$ as an alkaline activator.

main hydration process of fresh and hardened slag based $\mathrm{NaAlO}_{2}$ as an alkaline activator.

\section{Conclusions}

The effects of $\mathrm{NaAlO}_{2}$ dosage and $\mathrm{Na}_{2} \mathrm{O}$ content on the setting time, fluidity, compressive strength, and microstructures of AAS paste were studied. The solid alkaline activator was convenient for experimental operation. The main conclusions of the article were as follows.

(1) Both $\mathrm{NaAlO}_{2}$ dosage and $\mathrm{Na}_{2} \mathrm{O}$ content were critical points of the AAS paste properties.

(2) The setting time could be increased by adding $\mathrm{NaAlO}_{2}$ and decreasing the $\mathrm{Na}_{2} \mathrm{O}$ content.

(3) The addition of $\mathrm{NaAlO}_{2}$ had a great contribution to the late phase of the hydration reaction process that resulted in higher compressive strength.

(4) With adding $\mathrm{NaAlO}_{2}$, the AAS microstructure became denser and the pore decreased in the late phase of hydration reaction. The main reaction products were $\mathrm{C}-\mathrm{S}-\mathrm{H}(\mathrm{I})$, gismondine, calcite, and tetranatrolite; the amount of tetranatrolite products increased by $\mathrm{NaAlO}_{2}$ elevating.
(5) $\mathrm{NaAlO}_{2}$ hydration produced $\mathrm{Al} 3+$ and $\mathrm{OH}^{-}$ions; the coating of the Al3+ ions on the surface of slag particles inhibited the early-phase hydration reaction, prolonged the setting time, and promoted the formation of high cross-linked gels in the late phase of hydration reaction resulting in improving the compressive strength. However, the $\mathrm{OH}^{-}$ions provided sufficient hydration power which ensured that AAS could obtain better mechanical properties in both the early phase and later phase of hydration reaction.

\section{Data Availability}

All data used to support the findings of this study are available from the corresponding author upon request.

\section{Conflicts of Interest}

The authors declare that they have no conflicts of interest.

\section{Acknowledgments}

This study was sponsored by the project of Heilongjiang Traffic and Transportation Department (JTZD-20181826). 


\section{References}

[1] M. Azhar Khan, M. Zahir Khan, K. Zaman, and L. Naz, "Global estimates of energy consumption and greenhouse gas emissions," Renewable and Sustainable Energy Reviews, vol. 29, pp. 336-344, 2014.

[2] E. Gartner and H. Hirao, "A review of alternative approaches to the reduction of $\mathrm{CO}_{2}$ emissions associated with the manufacture of the binder phase in concrete," Cement and Concrete Research, vol. 78, pp. 126-142, 2015.

[3] Z. Jiao, Y. Wang, W. Zheng, and W. Huang, "Effect of dosage of alkaline activator on the properties of alkali-activated slag pastes," Advances in Materials Science and Engineering, vol. 2018, Article ID 8407380, 12 pages, 2018.

[4] F. Wang, G. Chen, L. Ji, and Z. Yuan, "Preparation and mechanical properties of cemented uranium tailing backfill based on alkali-activated slag," Advances in Materials Science and Engineering, vol. 2020, Article ID 6345206, 7 pages, 2020.

[5] T. Zhang, H. Jin, L. Guo et al., "Mechanism of alkali-activated copper-nickel slag material," Advances in Civil Engineering, vol. 2020, Article ID 7615848, 10 pages, 2020.

[6] Z. Jiao, Y. Wang, W. Zheng, and W. Huang, "Effect of dosage of sodium carbonate on the strength and drying shrinkage of sodium hydroxide based alkali-activated slag paste," Construction and Building Materials, vol. 179, pp. 11-24, 2018.

[7] C. Duran Atiş, C. Bilim, Ö. Çelik, and O. Karahan, "Influence of activator on the strength and drying shrinkage of alkaliactivated slag mortar," Construction and Building Materials, vol. 23, pp. 548-555, 2009.

[8] A. M. Rashad, Y. Bai, P. A. M. Basheer, N. B. Milestone, and N. C. Collier, "Hydration and properties of sodium sulfate activated slag," Cement and Concrete Composites, vol. 37, pp. 20-29, 2013.

[9] A. R. Sakulich, E. Anderson, C. L. Schauer, and M. W. Barsoum, "Influence of Si:Al ratio on the microstructural and mechanical properties of a fine-limestone aggregate alkali-activated slag concrete," Materials and Structures, vol. 43, no. 7, pp. 1025-1035, 2010.

[10] Y. Huang and M. Han, "The influence of $\alpha$-Al2O3 addition on microstructure, mechanical and formaldehyde adsorption properties of fly ash-based geopolymer products," Journal of Hazardous Materials, vol. 193, pp. 90-94, 2011.

[11] M. B. Haha, B. Lothenbach, G. Le Saout, and F. Winnefeld, "Influence of slag chemistry on the hydration of alkaliactivated blast-furnace slag-Part II: effect of $\mathrm{Al}_{2} \mathrm{O}_{3}$," Cement and Concrete Research, vol. 42, no. 1, pp. 74-83, 2012.

[12] China Standards Press, "Ground granulated blast furnace slag used for cement, mortar and concrete," GB/T 18046-2017, p. 2, China Standards Press, Beijing, ChinaChina Standards Press, 2018.

[13] China Standards Press, "S. A. of the P. R. of test methods for water requirement of normal consistency, setting time and soundness of the Portland cement," GB/T 1346-2011, p. 6, China Standards Press, Beijing, ChinaChina Standards Press, 2011.

[14] China Standards Press, "Methods for testing uniformity of concrete admixture," China Standards Press, Beijing, China, p. 15, 2012 , GB/T 8077-2012.

[15] China Standards Press, "State bureau of quality and technical supervision," China Standards Press, Beijing, China, GB/T 17671-1999, 1999.

[16] S. Aydin and B. Baradan, "Effect of activator type and content on properties of alkali-activated slag mortars," Composites Part B: Engineering, vol. 57, pp. 166-172, 2014.
[17] T. Bakharev, J. G. Sanjayan, and Y.-B. Cheng, "Sulfate attack on alkali-activated slag concrete," Cement and Concrete Research, vol. 32, no. 2, pp. 211-216, 2002.

[18] I. García-Lodeiro, N. Cherfa, F. Zibouche, A. FernándezJimenez, and A. Palomo, "The role of aluminium in alkaliactivated bentonites," Materials and Structures, vol. 48, no. 3, pp. 585-597, 2015.

[19] H. Mehdizadeh and E. Najafi Kani, "Rheology and apparent activation energy of alkali activated phosphorous slag," Construction and Building Materials, vol. 171, pp. 197-204, 2018.

[20] K. Sasaki, K. Kurumisawa, and K. Ibayashi, "Effect of retarders on flow and strength development of alkali-activated fly ash/ blast furnace slag composite," Construction and Building Materials, vol. 216, pp. 337-346, 2019.

[21] F. Xie, Z. Liu, D. Zhang, J. Wang, D. Wang, and J. Ni, “The effect of $\mathrm{NaOH}$ content on rheological properties, microstructures and interfacial characteristic of alkali activated phosphorus slag fresh pastes," Construction and Building Materials, vol. 252, p. 119132, 2020.

[22] F. Puertas, C. Varga, and M. M. Alonso, "Rheology of alkaliactivated slag pastes. Effect of the nature and concentration of the activating solution," Cement and Concrete Composites, vol. 53, pp. 279-288, 2014.

[23] A. F. Abdalqader, F. Jin, and A. Al-Tabbaa, "Development of greener alkali-activated cement: utilisation of sodium carbonate for activating slag and fly ash mixtures," Journal of Cleaner Production, vol. 113, pp. 66-75, 2016.

[24] A. Fernández-Jiménez, J. G. Palomo, and F. Puertas, "Alkaliactivated slag mortars," Cement and Concrete Research, vol. 29, no. 8, pp. 1313-1321, 1999.

[25] M. Kovtun, E. P. Kearsley, and J. Shekhovtsova, "Chemical acceleration of a neutral granulated blast-furnace slag activated by sodium carbonate," Cement and Concrete Research, vol. 72, pp. 1-9, 2015.

[26] C. Shi and J. Qian, "High performance cementing materials from industrial slags-a review," Resources, Conservation and Recycling, vol. 29, no. 3, pp. 195-207, 2000.

[27] K. Komnitsas, D. Zaharaki, and V. Perdikatsis, "Effect of synthesis parameters on the compressive strength of lowcalcium ferronickel slag inorganic polymers," Journal of Hazardous Materials, vol. 161, no. 2-3, pp. 760-768, 2009.

[28] S. J. Bae, S. Park, and H. K. Lee, "Role of Al in the crystal growth of alkali-activated fly ash and slag under a hydrothermal condition," Construction and Building Materials, vol. 239, p. 117842, 2020.

[29] H. R. Khalid, N. K. Lee, S. M. Park, N. Abbas, and H. K. Lee, "Synthesis of geopolymer-supported zeolites via robust onestep method and their adsorption potential," Journal of Hazardous Materials, vol. 353, pp. 522-533, 2018.

[30] S. A. Bernal, R. San Nicolas, R. J. Myers et al., " $\mathrm{MgO}$ content of slag controls phase evolution and structural changes induced by accelerated carbonation in alkali-activated binders," $\mathrm{Ce}$ ment and Concrete Research, vol. 57, pp. 33-43, 2014.

[31] R. Cao, S. Zhang, N. Banthia, Y. Zhang, and Z. Zhang, "Interpreting the early-age reaction process of alkali-activated slag by using combined embedded ultrasonic measurement, thermal analysis, XRD, FTIR and SEM," Composites Part B: Engineering, vol. 186, p. 107840, 2020.

[32] A. Fernández-Jiménez, A. Palomo, I. Sobrados, and J. Sanz, "The role played by the reactive alumina content in the alkaline activation of fly ashes," Microporous and Mesoporous Materials, vol. 91, no. 1-3, pp. 111-119, 2006. 
[33] A. Gharzouni, L. Ouamara, I. Sobrados, and S. Rossignol, "Alkali-activated materials from different aluminosilicate sources: effect of aluminum and calcium availability," Journal of Non-crystalline Solids, vol. 484, pp. 14-25, 2018.

[34] Y.-S. Wang, J. L. Provis, and J.-G. Dai, "Role of soluble aluminum species in the activating solution for synthesis of silico-aluminophosphate geopolymers," Cement and Concrete Composites, vol. 93, pp. 186-195, 2018.

[35] T. Huang, L. Zhou, L. Chen, W. Liu, S. Zhang, and L. Liu, "Mechanism exploration on the aluminum supplementation coupling the electrokinetics-activating geopolymerization that reinforces the solidification of the municipal solid waste incineration fly ashes," Waste Management, vol. 103, pp. 361-369, 2020. 